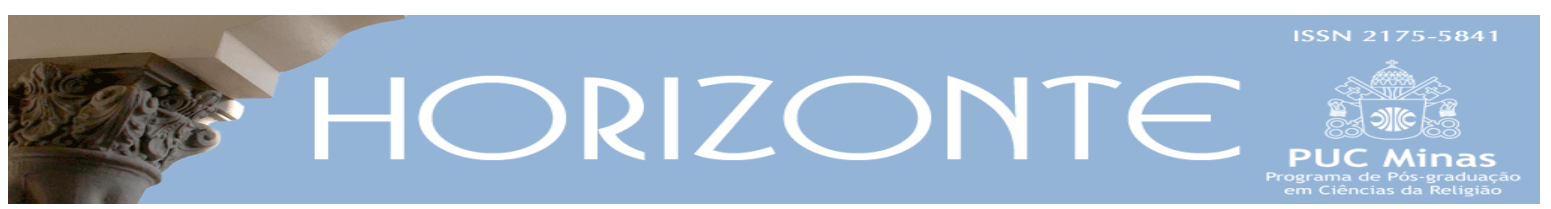

Dossiê: Conferência de Puebla: 40 anos - Artigo original (c) (1)

\title{
O clamor dos pobres: uma interpelação à consciência religiosa e à fé cristã
}

\author{
The cry of the poor: \\ an appeal to religious conscience and the Christian faith
}

João Luiz Correia Júnior*

Drance Elias da Silva**

\begin{abstract}
Resumo
O clamor dos pobres, tema deste trabalho, interpela a consciência humanitária das pessoas e é um forte questionamento à consciência religiosa e à fé cristã. Apesar disso, a opção preferencial pelos pobres, consagrada no Documento final da Conferência Episcopal realizada em Puebla de Los Angeles, é causa, até hoje, de muitas controvérsias dentro e fora da Igreja. Tendo presente esse contexto, o presente artigo tem como objetivo apresentar a ressonância do clamor dos pobres no contexto da Conferência de Puebla; demonstrar que esse clamor não é recente: está presente desde a Antiguidade, e foi contemplado nos primeiros textos sagrados, inclusive da cultura religiosa de Israel e da Religião Cristã; repercutir sobre esse clamor das multidões empobrecidas, na contemporaneidade. A pesquisa é bibliográfica, a partir do Documento Oficial das conclusões da Conferência de Puebla; de análises críticas feitas por teólogos latino-americanos, bem como de artigos e livros de autores do campo epistemológico das Ciências da Religião. Os resultados alcançados apontam sobre a atualidade do tema, uma vez que observa-se em toda parte uma crescente onda de empobrecimento e, ao mesmo tempo, um crescente descompromisso e intolerância para com o clamor das grandes massas excluídas.
\end{abstract}

Palavras-chave: Religião. Judaísmo. Cristianismo. Teologia. Ciências da Religião.

\begin{abstract}
The cry of the poor, the theme of this work, challenges the humanitarian consciousness of the people and is a strong questioning of the religious conscience and the Christian faith. Nevertheless, the preferential option for the poor, consecrated in the Final Document of the Episcopal Conference held in Puebla of Los Angeles, is still the cause of much controversy inside and outside the Church. Bearing in mind this context, this article aims to present the resonance of the cry of the poor in the context of the Puebla Conference; demonstrate that this cry is not recent: it has been present since antiquity, and was contemplated in the earliest sacred texts, including the religious culture of Israel and the Christian religion; to reflect on this cry of impoverished crowds in contemporary times. The research is bibliographic, based on the Official Document of the conclusions of the Puebla Conference; from critical analysis by Latin American theologians, as well as from articles and books by authors from the epistemological field of the Sciences of Religion. The results achieved point to the timeliness of the issue, as there is a growing wave of impoverishment everywhere and, at the same time, a growing lack of commitment and intolerance towards the outcry of the great excluded masses.
\end{abstract}

Keywords: Religion. Judaism. Christianity. Theology. Sciences of Religion.

\footnotetext{
Artigo submetido em 29 de agosto de 2019 e aprovado em 26 de dezembro de 2019.

* Doutor em Teologia pela PUC-RIO. Professor do Programa de Pós-graduação em Teologia e do Programa de Pós-graduação em Ciências da Religião da UNICAP. País de origem: Brasil. E-mail: joao.correia@unicap.br

** Doutor em Sociologia pela UFPE. Professor do Programa de Pós-graduação em Ciências da Religião da UNICAP. País de origem: Brasil. E-mail: dranceelias1991@gmail.com
} 


\section{Introdução}

O clamor das camadas sociais vítimas da estrutura social injusta e excludente foi-se tornando, ao longo da história, uma ameaça aos privilegiados e, ao mesmo tempo, uma interpelação à consciência das pessoas de boa-vontade. Apesar disso, na Igreja Católica da América Latina, a causa dos pobres contemplada na opção preferencial pelos pobres é, até hoje, motivo de controvérsias. O termo foi consagrado há quarenta anos no documento final das conclusões da Conferência Geral do Episcopado Latino-americano, realizado em Puebla de los Angeles, México, de 21/o1 a 13/o2 de 1979. Muitas pessoas da própria Igreja Católica ainda questionam: será uma “opção” algo excludente? Ao se fazer opção, mesmo que seja "preferencial” pelos pobres, não se faz "acepção de pessoas", o que é criticado na Bíblia e, de modo especial, nos Evangelhos? Como ficam os ricos, que tanto apoiam as obras sociais da Igreja? Terá sido uma opção circunstancial, influenciada pela corrente teológica latino-americana conhecida como Teologia da Libertação, muito influente naquela época?

Quem trabalha na formação cristã do laicato, ou mesmo nas Universidades ministrando aulas em disciplinas teológicas, sabe que, constantemente, volta-se aos mesmos questionamentos. Por isso o tema continua atual e instigante, para quem reflete seriamente sobre o sentido da fé cristã em meio aos desafios do tempo presente.

Logo nas páginas iniciais do Documento de Puebla (DP)르, na "Mensagem aos Povos da América Latina”, está contemplada uma verdade inconveniente para as pessoas que se mantêm na zona de conforto de uma fé alienada dos inúmeros desafios sociais, descomprometidas com a causa dos empobrecidos:

Lançando um olhar sobre nosso mundo latino-americano, com que espetáculo deparamos? Não se faz mister aprofundar o exame. A verdade é que aumenta, cada dia mais, a distância entre os muitos que têm pouco e os poucos que têm muito. Estão ameaçados os valores de nossa cultura. Estão sendo violados os direitos fundamentais do ser humano. (DOCUMENTO DE PUEBLA, 1979, p. 75).

\footnotetext{
${ }^{1}$ Ao longo deste trabalho, a sigla "DP" será utilizada nas referências a parágrafos do Documento de Puebla.
} 
Interpelados por essa distância cada vez maior "entre os muitos que têm pouco e os poucos que têm muito”, os conferencistas fazem uma declaração de fé:

Cremos que a revisão do comportamento religioso e moral dos homens deve refletir-se na esfera do processo político e econômico de nossos países; por isso convidamos a todos, sem distinção de classes, a que aceitem e assumam a causa dos pobres, como se estivessem assumindo e aceitando sua própria causa, a própria causa de Jesus Cristo. "Tudo o que fizestes a um desses meus irmãos mais pequeninos a mim o fizestes" (Mt 25,40). (DOCUMENTO DE PUEBLA, 1979, p. 78).

Ao comentar essa declaração, o teólogo Ney de Souza chegou a afirmar que “a intensidade e dramaticidade destas palavras e a apelação ao juízo último de Deus ilustram a grandeza de ânimo dos bispos reunidos em Puebla, atormentados pelos sofrimentos dos povos latino-americanos" (SOUZA, 2019, p. 80). De fato, a miséria, o sofrimento e o clamor dos pobres interpelaram e interpelam a consciência cristã na América Latina, em meio ao empobrecimento constante e crescente de grandes aglomerados humanos no Continente latino-americano e no mundo.

Neste artigo, retoma-se a interpelação do clamor dos pobres na Conferência Episcopal de Puebla; faz-se memória desse clamor ao longo da história, perseguindo-se alguns registros da interpelação causada pela situação dos empobrecidos em textos religiosos de culturas antigas, até chegar a textos da cultura religiosa de Israel, contemplados na Bíblia. Por fim, busca-se repercutir sobre o clamor dos pobres, na contemporaneidade.

\section{0 clamor dos pobres na Conferência de Puebla}

O clamor dos pobres ecoa no Documento de Puebla como interpelação à prática da justiça e à defesa dos direitos humanos: “Do coração dos vários países que formam a AL está subindo ao céu um clamor cada vez mais impressionante. É o grito de um povo que sofre e que reclama justiça, liberdade e respeito aos direitos fundamentais dos homens e dos povos." (DP 87). 
Inspirados no Discurso de Abertura da Conferência, feito pelo Papa João Paulo II, os Bispos latino-americanos afirmam que é "um escândalo e uma contradição com o ser cristão, a brecha crescente entre ricos e pobres”. Denunciam que "o luxo de alguns poucos converte-se em insulto contra a miséria das grandes massas”. Do ponto de vista teológico, tal situação é concebida pelos Bispos como contrária ao plano do Criador e à honra que lhe é devida. Esse "pecado social" é, ainda mais grave, quanto se dá em países que se dizem católicos, e que têm capacidade de mudar. (DP 28).

Os Bispos da Conferência de Puebla reconhecem que esse "clamor surdo" de milhões de pessoas já era observado na Conferência Episcopal de Medellín, realizado há mais de dez anos. Mas, agora, esse clamor "é claro, crescente, impetuoso e, nalguns casos, ameaçador" (DP 88-89).

Tal situação é assumida, então, no Documento de Puebla, como desafio à ação evangelizadora: "As profundas diferenças sociais, a extrema pobreza e a violação dos direitos humanos - que ocorrem em muitas regiões - são desafios lançados à evangelização.” (DP 90).

Mas, paradoxalmente, os próprios Bispos reconhecem que esta situação social tem acarretado tensões no seio da Igreja: "tensões produzidas ou por grupos que enfatizam 'o espiritual' de sua missão, ressentindo-se dos seus trabalhos de promoção social ou por grupos determinados a transformar a missão da Igreja em mero trabalho de promoção humana." (DP 90).

Contudo, na visão do teólogo José Comblin, em interessante artigo intitulado "Puebla: vinte anos depois", a tensão entre grupos dentro da Igreja latino-americana era ainda mais grave:

Para o movimento da Igreja da libertação, a primeira urgência na América Latina era a opressão das massas pobres e a necessidade de promoção humana de povos cuja situação de opressão estava agravada pelos regimes miliares instalados por iniciativa dos Estados Unidos. Por um lado, opção pelos pobres; do outro lado, opção pelo status quo, isto é, a aliança com as classes dominantes e com os militares. No partido da opção pelos pobres, estavam [na Conferência de Puebla] a maioria dos brasileiros, chilenos, peruanos e alguns representantes de outras nações. (COMBLIN, 1999, p. 205-206). 
Sabiamente, Comblin chega a afirmar que "a Assembleia de Puebla foi uma dramatização dos acontecimentos que faziam a história da América Latina daquele tempo: por um lado a guerra contra o marxismo, e por outro, a libertação dos pobres oprimidos.” (COMBLIN, 1999, p. 206).

Na perspectiva libertadora, a “opção preferencial pelos pobres” não exclui ninguém; pelo contrário, tem como objetivo incluir, ajudando pastoralmente as pessoas a passarem - elas mesmas - de situações degradantes para situações em que sejam dignificadoras da natureza humana. A opção por eles consiste, portanto, em (re)dignificá-los e (re)empoderá-los (DP 1134-1137).

E essa ação libertadora passa pelo crivo da urgência. Os Bispos, reunidos em Puebla, têm consciência de que a situação dos pobres agrava-se em todo o continente. Os pobres não carecem apenas de bens materiais, mas também, no plano da dignidade humana, carecem de uma plena participação social e política. Nessa categoria se encontram principalmente indígenas, camponeses, operários, marginalizados pela cidade e, especialmente, a mulher desses setores sociais, por sua condição duplamente oprimida e marginalizada (DP 1135). ${ }^{2}$

A opção preferencial pelos pobres é um imperativo ético à ação prática motivada pela fé e, consequentemente, interpela a necessidade de "conversão de toda a Igreja, no intuito de sua integral libertação” (DP 1134). Sobre essa afirmativa, em 1988, quase 10 anos depois da Conferência de Puebla, o teólogo Leonardo Boff fez um questionamento tão inquietante quanto pertinente:

O enunciado confessa que a Igreja que opta preferencialmente pelos pobres não é ainda a Igreja dos pobres; trata-se de uma Igreja que, historicamente, se encontrava comprometida com as classes não-pobres e que, nos últimos anos e agora com mais determinação, assume a causa dos pobres e se propõe entrar num processo que deve culminar na gestação de uma Igreja preferencialmente dos pobres e de uma sociedade que supera a pobreza, não pela riqueza, mas pela justiça. (BOFF, 1988, p. 129).

\footnotetext{
${ }^{2}$ Conferir, também, DP 1135, nota de rodapé 331 .
} 
De algum modo, os Bispos reunidos em Puebla têm consciência dessa distância da Igreja para com os pobres. Contudo, deixaram claro, no Documento final da Conferência, o seguinte:

Verificamos que episcopados nacionais e numerosos setores de leigos(as), religiosos(as) e sacerdotes tornaram mais profundo e realista o seu compromisso com os pobres. Esse testemunho incipiente, mas real, levou a Igreja latino-americana à denúncia das graves injustiças derivadas de mecanismos opressores. (DP 1136).

É uma constatação otimista no que tange à opção preferencial pelos pobres. No período entre a Conferência de Medellín e a de Puebla, verificou-se que os pobres foram, gradativamente, (re)empoderando-se de sua dignidade: “os pobres, também alentados pela Igreja, começaram a organizar-se para uma vivência integral de sua fé e, por isso, para reivindicar os seus direitos.” (DP 1137).

Sem dúvida, a opção preferencial pelos pobres foi reconhecida como de muitíssima importância para a Igreja latino-americana. Como afirmou Leonardo Boff em 1988:

Estimo que com esta opção preferencial pelos pobres se produziu a grande e necessária revolução copernicana no seio da Igreja, cujo significado desborda do contexto eclesial latino-americano concernindo a Igreja universal. Sinceramente creio que esta opção significa a mudança teológico-pastoral mais importante ocorrida depois da Reforma Protestante no século XVI. Por ela se define um novo lugar histórico-social a partir de onde a Igreja quer estar presente na sociedade e construir-se a si mesma, isto é, no meio dos pobres como os novos sujeitos emergentes da história. (BOFF, 1988, p. 129-130).

As pessoas empobrecidas, alentadas pela Igreja, ao serem (re)empoderadas de sua dignidade, recebem novo sopro de vida: "começam a organizar-se para uma vivência integral de sua fé e, por isso, para reivindicar os seus direitos.” (DP 1137).

Não é de estranhar que esse reempoderamento dos pobres causa-lhes, em não poucos casos, perseguições e vexames (DP 1138). A opção preferencial pelos pobres é uma denúncia profética da Igreja sobre a situação de injustiça social em que grandes massas estão submetidas na América Latina. Como toda denúncia, a 
opção preferencial pelos pobres aguça os conflitos já existentes e atrai ainda mais perseguições: a) dos poderes políticos e econômicos, promotores e ou coniventes com essa opressão; b) da polícia e de forças paramilitares que prestam serviço aos poderes acima citados; c) do poder ideológico que está por trás de setores da grande imprensa, que filtram as notícias de acordo com os interesses da classe dominante.

Foi nesse contexto que, em 1976, ainda em clima da Conferência Episcopal Latino-americana de Medellín (1968), Dom Hélder Câmara, em sua crônica diária transmitida pela Rádio Olinda, PE, esclareceu alguns pontos que valem a pena destacar sobre "Opção pelos pobres":

Será verdade que quando se faz uma opção, faz-se uma exclusão? Opção é preferência, sem excluir ninguém... Opção pelos pobres é aceitar sofrer por eles, pela defesa dos seus direitos. Opção pelos pobres é não admitir a miséria que é insulto ao Criador e Pai... Opção é exclusão para criaturas exclusivistas. Há quem só saiba amar o pobre, odiando o rico. É possível e desejável amar a todos, pobres e ricos. Apenas, se optamos conscientemente pelos pobres iremos defendê-los. E a melhor maneira de defender os pobres consiste em ajudar a criar condições para que eles se bastem, possam caminhar com os próprios pés e usar a própria cabeça. A melhor maneira de ajudar os ricos consiste em ajudá-los a aprender a arte dificílima de utilizar a riqueza como instrumento, em lugar de deixar que ela assuma o lugar de Senhora, Dominadora e Deusa. Opção não é exclusão. É preferência. Já notaram que a faz falta ter opções? Não responda a mim. Respondam à própria consciência! (ROZOWYKWIAT, 2016, p. 95-96).

Essa incompreensão sobre a "opção [preferencial] pelos pobres" ocorre porque nem sempre a Igreja latino-americana se preocupou com essa grande multidão de empobrecidos e excluídos sociais. Os Bispos da III Conferência Episcopal deixaram, no Documento de Puebla, um mea culpa:

Na Igreja da América Latina, nem todos nos temos comprometido bastante com os pobres; nem sempre nos preocupamos com eles e somos com eles solidários. O serviço do pobre exige, de fato, uma conversão e purificação constante, em todos os cristãos, para conseguir-se uma identificação cada dia mais plena com Cristo pobre e com os pobres. (DP 1140). 
Trata-se de uma confissão pública, muito oportuna, de que o compromisso efetivo com a causa dos pobres não é unanimidade na Igreja latino-americana. Muitas pessoas permanecem surdas ao clamor dos pobres por justiça, dignidade e direitos iguais. E o mais grave é que esse clamor não é algo recente na história: é tão antigo quanto a própria civilização humana.

O clamor dos pobres que interpela a consciência das pessoas está contemplado em escritos importantes de culturas antigas, conforme se percebe em textos sagrados de algumas Religiões e, de modo especial, das Religiões judaica e cristã. Este tema é apresentado a seguir.

\section{0 clamor dos pobres no mundo antigo}

Há cerca de dez mil anos, houve um importante desenvolvimento da agricultura e da pecuária no chamado Crescente Fértil do Oriente Médio, que se convencionou chamar de "revolução agrícola", propiciando o armazenamento do excesso da produção3.

Contudo, esses alimentos extras não se traduziram em uma dieta melhor ou em mais lazer. Em vez disso, segundo Harari (2018, p. 89), "se traduziram em explosões populacionais e elites favoráveis. Em média, um agricultor trabalhava mais que um caçador-coletor e obtinha em toca uma dieta pior”.

Beneficiados pela mão de obra excedente, alguns grupos se locupletam do trabalho alheio e passam a concentrar a riqueza em suas mãos. O empobrecimento crescente e o clamor das camadas sociais menos favorecidas foram-se tornando algo ameaçador para as camadas privilegiadas dos médios e grandes aglomerados humanos.

\footnotetext{
${ }^{3}$ Esse desenvolvimento da agricultura começou por volta de 9500-8500 a.C. no interior montanhoso do sudeste da Turquia, no oeste do Irã e no Levante. Trigo e bodes foram domesticados por volta de 9000 a.C.; ervilhas e lentilhas, em torno de 8000 a.C.; oliveiras, cerca de 5000 a.C.; cavalos, por volta de 4000 a.C.; e videiras, em 3500 a.C. Alguns animais e sementes, como camelos e castanhas-decaju, foram domesticados ainda mais tarde, mas em 3500 a.C., a principal onda de domesticação havia chegado ao fim. Mesmo hoj e, com toda a nossa tecnologia avançada, mais de $90 \%$ das calorias que alimentam a humanidade vêm do punhado de plantas que nos sos ancestrais domesticaram entre 9500 e 3500 a.C. - trigo, arroz, milho, batata, painço e cevada. (HARARI, 2018, p. 87).
} 
Além de ameaçar a estrutura social injusta e excludente, o clamor dos pobres passou a ser também uma dura interpelação à consciência religiosa, conforme o atestam alguns dos livros sagrados, a partir do segundo milênio a.C.. Segundo Mircea Eliade (2010), crises espirituais em consequência do silêncio dos deuses diante da miséria de milhares de pessoas explodiram em diversos recantos do mundo antigo. Respostas, com consequências diversas, foram dadas de acordo com a cultura religiosa de cada povo do mundo antigo (ELIADE, 2010, p. 87).

Na Religião do Antigo Egito, em Textos Sagrados como o Livro dos Mortos 4 , já se configurava a crença no julgamento dos finados a partir de critérios éticos na relação com os menos favorecidos da sociedade, os pobres:

Osíris, Deus do julgamento, juiz dos mortos, presidia um tribunal assessorado por 42 juízes, perante o qual compareciam os mortos para o julgamento final. As divindades Horus e Anúbis apanhavam o coração do morto e pesavam em uma balança de dois braços com o contrapeso de uma figura de Ma'at (deusa da justiça). Se o coração pesava menos, era levado a Osíris por Horus, a fim de ser introduzido em seu reino. $\mathrm{O}$ julgamento era feito segundo um questionário minucioso, de que temos vários exemplares, e onde aparecem não raro textos de sentido moral, como este:

-Eu não causei dano a pessoas ou animais...

-Eu não oprimi os pobres em seus bens...

-Não fiz ninguém chorar...

-Não matei, não mandei matar...

-Não roubei...

-Não tive relações ilícitas...

-Não alterei a medida do trigo...

-Não alterei os pesos...

-Eu sou puro... etc.5 (PIAZZA, 1991, p. 81-82).

Como se percebe no trecho acima do "Livro dos Mortos", o ser humano já assume e configura dimensões divinas à sua vida. Mantendo-se em ligação como o universo que o cerca, responsabiliza-se por ele, e sua responsabilidade permanece

\footnotetext{
${ }^{4}$ No Egito, junto com as primeiras inscrições mágicas, descobriram-se testemunhos escritos das primeiras angústias e esperanças humanas em face do mistério da morte. No "Livro dos Mortos" (cujo título mais próximo do original seria "Saída para a luz do dia"), o finado é julgado por Osíris, o Deus solar. O tema central é a vontade de abolir o limite, a barreira entre a vida e a morte, entre o homem e o divino (GARAUDY, 1981, p. 79).

${ }^{5}$ Segundo Severino Croatto, essa Declaração de inocência, que consta do capítulo 125 do Livro dos Mortos (Egito, Dinastia XVIII, do século XVI a.C.), é um texto que pode ser comparado com outro, da cultura religiosa judaica, Jó 31,7ss, num contexto de "protesto" perante Deus (CROATTO, 2001, p. 5009-510). Contudo, lastima-se Waldomiro Piazza, "infelizmente, a mentalidade pragmática dos egípcios, explorada pela ganância dos encarregados dos ritos fúnebres, transformou essa tendência da reflexão religiosa egípcia em ritos mágicos, dando crédito a "confissões negativas" (eu não menti, eu não matei, eu não oprimi os pobres, etc.), feitas de encomenda e artisticamente elaboradas, para servir de "passaporte" para a eternidade [...]" (PIAZZA, 1991, p. 80).
} 
mesmo depois de sua vida, que é inseparável do Todo. Diante de Osíris, deus dos vivos e dos mortos, o ser humano dá satisfação de sua conduta ética e moral, em vida. (GARAUDY, 1981, p. 80).

Na antiga Mesopotâmia, um dos textos célebres é o "Diálogo sobre a miséria humana", também conhecido como o "Eclesiastes babilônico"6. Mircea Eliade (2010) apresenta fragmentos literários desse texto, acrescentando algumas frases para melhor compreensão do leitor. No texto destacado, o eu lírico questiona o abandono das divindades, em meio à injusta miséria que sofre, apesar de ser justo e piedoso:

Será que o altivo leão, que se alimenta da melhor carne, apresenta sua oferenda de incenso a fim de aplacar a contrariedade da deusa?... [Quanto a mim], não terei feito a oblação? [Não], Orei aos deuses, ofereci os sacrifícios previstos às deusas

Desde a infância, esse justo esforçou-se por compreender o pensamento do deus; humilde e piedosos, buscou a deusa. No entanto, "o deus trouxeme a penúria em vez da riqueza”.

E, contudo, foi o criminoso, o ímpio que amontoou a riqueza.

A multidão ouve a palavra de um homem preeminente, especialista em crime, mas vilipendia o humilde ser que não se serve da violência. " $O$ malfeitor é justificado, e o justo, repelido". Enquanto o bandido recebe o ouro, o fraco passa fome. Reforça-se ainda mais o poder do pérfido, enquanto se arruína o inválido e se abate o fraco. (ELIADE, 2010, p. 87).

O texto acima surge da experiência realista de quem sofre a injustiça na própria pele: os maus triunfam na vida, enquanto que as orações do justo não surtem o menor efeito; os deuses parecem indiferentes aos problemas do pobre. O eu lírico é um justo sofredor que interpela as divindades a sua inércia.

Na continuidade do texto "O Diálogo sobre a Miséria Humana", enquanto o justo padece de incontáveis deformidades que o levavam a “chafurdar nos próprios

\footnotetext{
${ }^{6}$ Esse texto surgiu durante o domínio do povo casita, da região do Cáucaso, na Babilônia (1530 a 1130 a. C.). Foram anos de fraqueza política e empobrecimento. Isso levou a casta sacerdotal a se questionar por que os deuses haviam deixado o país? Chegaram a conclusão de que o abandono dos deuses ocorreu por causa do mau comportamento humano. Para que as divindades protegessem as pessoas, elas tinham que ter boa conduta moral e ética; a cada pecado correspondia uma punição. Mas por que, nesse contexto, o justo sofre também? Uma obra que trabalha sobre esse tema, denominada "Dialogo sobre la miseria humana!" (2009) surge para insistir na tese da insuficiência da moralidade humana e da inutilidade do esforço humano para corresponder à justiça divina.
} 
excrementos”, e os seus já o choravam como a um morto, uma série de sonhos lhe revela que o Deus Marduk iria salvá-lo. Ele próprio vê o deus derrotando os demônios da doença e arrancando-lhe depois as dores do corpo, como se tiram as raízes a uma planta. Finalmente, recuperada a saúde, o justo rende graças a Marduk atravessando ritualmente as 12 portas de seu templo em Babilônia. (ELIADE, 2010, p. 88-89).

Na Índia, o Budismo apresenta como o primeiro atributo da iluminação a Sabedoria, consequência da compreensão profunda do que está por trás da realidade visível. Dessa compreensão, fluem naturalmente as Quatro Nobres Virtudes: bondade, compaixão, serenidade e alegria com a felicidade e bem-estar dos outros (SMITH, 2007, p. 126-127). A compaixão é ação gratuita, voltada tão somente para o bem dos outros. Nesse aspecto, os budistas sempre se preocuparam com os pobres e enfermos. A disposição para as doações e para a beneficência pertence ao número das virtudes básicas recomendadas por Buda a seus adeptos. (SCHERER, 2005, p. 127).

No Antigo Israel, a miséria, o sofrimento e o clamor dos pobres, além de interpelar à compaixão solidária, passou a ser uma interpelação assumida em favor dos pobres pelo Deus. Naquela cultura, não se exige simplesmente, do ponto de vista ético, não matar, não roubar, não mentir. Tais exigências passaram a ser também religiosas, reconhecidas como vontade de Deus. (KING, 2004, p. 191). É o que se percebe nas Sagradas Escrituras judaicas, conforme será abordado a seguir.

\section{0 clamor dos pobres na Bíblia}

No contexto histórico de origem do povo da bíblia, período do nomadismo, não havia grande distinção entre riqueza e pobreza, por conta de uma estreita interdependência entre família e clã e certo grau de comunidade de posse, especialmente dos rebanhos e manadas, de que os nômades vivem. Essas características protegem o indivíduo e o grupo menor contra necessidades extremas, pelo tempo em que o grupo tenha algo a partilhar. A sedentarização dos 
grupos que originalmente formaram Israel, o aumento da propriedade privada e a vida nas vilas e cidades, trouxe consigo maior responsabilidade individual no tocante à subsistência. A economia em expansão também trouxe o surgimento de uma classe rica e uma depressão das condições do camponês e do artesão. (MACKENZIE, 1983, p. 729, verbete “Pobre”).

Nesse contexto histórico, é significativo que a mais antiga coleção de leis de Israel, o Código da Aliança (Ex 20,22 - 23,33)7, já apresente estatutos de proteção ao pobre, como exigência divina. O código, considerado proveniente do próprio Deus, era dirigido ao povo de Israel através Moisés (conforme Ex 20,22: "Iahweh disse a Moisés: ‘Assim dirás aos israelitas...”).

Alguns trechos em que o Código da Aliança defende a causa dos mais pobres:

a) $\mathrm{O}$ devedor que se vende como escravo deve ser libertado sem qualquer compensação depois de seis anos, conforme Ex 21,1-2: "Eis as leis que lhes proporás: 'Quando comprares um escravo hebreu, seis anos ele servirá; mas no sétimo sairá livre, sem nada pagar""8.

b) No trecho do Código (Ex 22,20-26), o imigrante, o órfão, a viúva e o pobre são pessoas que não podem se defender: devem ser protegidas pelo direito. As necessidades vitais do ser humano estão acima de qualquer direito de propriedade:

Não afligirás o estrangeiro nem o oprimido, pois vós mesmos fostes estrangeiros no país do Egito.

Não afligirás nenhuma viúva ou órfão. Se o afligires e ele gritar [clamar] a mim, eu escutarei seu grito [clamor]; minha ira se acenderá e vos farei perecer pela espada: vossas mulheres ficarão viúvas e vossos filhos, órfãos. Se emprestares dinheiro a um compatriota, ao indigente que está em teu meio, não agirás com ele como credor que impõe juros.

Se tomares o manto do teu próximo em penhor, tu lho restituirás antes do pôr-do-sol. Porque é com ele que se cobre, é a veste do seu corpo: em que deitaria? Se clamar a mim, eu o ouvirei, porque sou compassivo. (Ex 22,20-26).

\footnotetext{
${ }^{7}$ A datação do Código da Aliança é discutida. A maioria dos críticos modernos julgam que em sua forma atual é do século IX ou do VIII, ou mesmo do século VII a.C. Admitem, no entanto, que contém elementos bem mais antigos, que remontam ao período dos juízes (DICIONÁRIO ENCICLOPÉDICO DA BÍBLIA, 2013, p. 59, verbete "Código da Aliança”).

${ }^{8}$ As referências bíblicas citadas neste artigo são da Bíblia de Jerusalém (2002).
} 
c) Em Ex 23,1-9, encontram-se aplicações do oitavo mandamento que orientam na administração da justiça em tribunais, onde, muitas vezes, o poderoso prevalece, torcendo o direito contra o pobre e o inocente. $\mathrm{O}$ «adversário» dos vv. 4-5 é a pessoa com quem se trava uma causa judicial. O v. 9 estimula a solidariedade: o povo deve respeitar aqueles que vivem na mesma situação que ele viveu no passado. Assim:

Não espalharás noticias falsas, nem darás a mão ao ímpio para seres testemunha de injustiça.

Não tomarás o partido da maioria para fazeres o mal, nem deporás num processo, inclinando-te para a maioria, para torcer o direito, nem serás parcial com o desvalido no seu processo.

Se encontrares o boi do teu inimigo, ou o seu jumento, desgarrado, lho reconduzirás. Se vires cair debaixo da canga o jumento daquele que te odeia, não o abandonarás, mas o ajudarás a erguê-lo.

Não desviarás o direito do teu pobre em seu processo.

Da falsa acusação te afastarás; não matarás o inocente e o justo, e não justificarás o culpado.

Não aceitarás presentes, porque os presentes cegam até os perspcazes e pervertem as palavras dos justos.

Não oprimirás o estrangeiro: conheceis a vida de estrangeiro, porque fostes estrangeiros no Egito. (Ex 23,1-9).

Em Ex 3,7-8.10, perícope que remonta ao século V a.C., provavelmente de tradição sacerdotal, está contemplada uma Teologia já bem elaborada, em que o Deus de Israel, Iahweh, aparece solidário com o "seu” povo que está no Egito:

Yahweh disse [a Moisés, do meio da sarça ardente]: "Eu vi, eu vi a miséria do meu povo que está no Egito. Ouvi seu grito por causa dos seus opressores; pois eu conheço as suas angústias. Por isso desci a fim de libertá-lo da mão dos egípcios, e para fazê-lo subir desta terra para uma terra boa e vasta, terra que mana leite e mel... Vai, pois, e eu te enviarei a Faraó para fazer sair do Egito o meu povo, os israelitas”. (Ex 3,7-8.10).

Percebe-se claramente aqui, nessa passagem do Êxodo, que o Deus da Bíblia se compadece da "aflição" humana em consequência da "miséria”, nível social mais baixo de indigência provocada pela opressão, em que o povo não tem como se 
defender, sem a ajuda do Altíssimo, que “desce” para libertá-lo. O clamor do pobre9 , em meio à miséria e opressão, atrai a compaixão divina.

Os profetas da Bíblia, cujo período áureo de atuação foi durante o tempo da Monarquia em Israel (1010-587 a.C.), criticaram duramente a classe dirigente por conta de posturas antiéticas contra os pobres. Isaías (que profetizou entre 731 e 701 a.C.) tem forte crítica aos que promulgam decretos iníquos, que escrevem sentenças de opressão para desapossarem os fracos do seu direito e privar da sua justiça aos pobres, para despojar as viúvas e saquear os órfãos (Is 10,1-4).

O clamor dos pobres interpela a consciência religiosa do povo de Israel. Nesse aspecto, o mesmo profeta Isaías critica duramente os que se acomodam às práticas religiosas ritualistas, desprovidas do compromisso ético com a causa dos pobres (Is 1,10-20). Nesses versículos, fica claro que o valor do culto não deve estar ligado apenas à multiplicação dos ritos (v. 12); o culto só pode ser oferecido por quem procura viver, no cotidiano, de acordo com as exigências de Deus, numa busca contínua de fidelidade que consiste em cessar de praticar o mal, aprender a fazer o bem, buscar a justiça em defesa do espoliado, do órfão e da viúva (vv. 16-17).

No Novo Testamento, os Evangelhos apresentam Jesus como o protagonista da chegada do Reino de Deus (Reino que desce dos Céus, lugar onde Deus habita, e se instala na terra, em meio aos reinos humanos). O evangelista Marcos, explicita isso claramente: "Depois que João foi preso, veio Jesus para a Galileia proclamando o Evangelho [a boa-notícia] de Deus: 'Cumpriu-se o tempo e o Reino de Deus está próximo. Arrependei-vos e crede no Evangelho’” (Mc 1,14-15).

Jesus proclamou a chegada do Reino de Deus (novos tempos messiânicos) não somente em sua pregação, mas, sobretudo, o fez por meio de sua ação missionária. Como afirmou o biblista italiano Giuseppe Barbaglio (1934-2007),

\footnotetext{
${ }^{9}$ Interessante notar que no Antigo Testamento há diversos termos hebraicos para expressar pobreza, mas nenhum deles pode ser traduzido exatamente por "pobre". A palavra 'anî é literalmente "aflito"; no uso, a aflição consiste em ser membro de uma classe mais baixa, indigente e sujeita à opressão, sem maios para se defender. A forma aramaizada correspondente, 'anaw é sinônimo, mas é frequentemente usada acerca dos pobres que não tem ânimo para resistir; daí significa literalmente "desfalecido", ou seja, uma classe social cujas fraqueza deriva da sua indigência. Por sua vez, o termo 'ebyon significa mais propriamente pobre e necessitado (MACKENZIE, 1983, p. 729, verbete "pobre").
} 
Jesus é o único hebreu da antiguidade conhecido por nós que proclamou não só a iminência do tempo final, mas, ao mesmo tempo, o início do novo tempo da salvação já no presente, e que tudo isso acontece pela sua ação. (BARBAGLIO, 2011, p. 264).

Nesses novos tempos messiânicos, Jesus age como o messias esperado, numa prática social voltada, sobretudo, para os mais pobres. Ele próprio dá testemunho dessa prática:

Quando Jesus terminou de dar essas instruções aos seus doze discípulos, partiu dali para ensinar e pregar nas cidades deles. João, ouvindo falar, na prisão, a respeito das obras de Cristo, enviou-lhes alguns dos seus discípulos para lhe perguntarem: "És tu aquele que há de vir, ou devemos esperar outro?” Jesus respondeu-lhes: "Ide contar a João o que ouvis e vedes: os cegos recuperam a vista, os coxos andam, os leprosos são purificados, os surdos ouvem, os mortos ressuscitam e os pobres são evangelizados. E bem-aventurado aquele que não se escandaliza por causa de mim!" (Mt 11,1-6). ${ }^{10}$

A resposta de Jesus nessa passagem está fundamentada nas Sagradas Escrituras do Profeta Isaías:

a) mortos ressuscitam (Is 26,19): Mas, os teus mortos hão de reviver e seus cadáveres se levantarão. Os que dormem no pó vão acordar e cantar, pois o teu orvalho é um orvalho de luz, e a terra das sombras dará à luz.

b) surdos ouvem, cegos veem (Is 29,18-19): Nesse dia, os surdos ouvirão as palavras do livro; e os olhos do cego, libertos da escuridão e das trevas, tornarão a ver. Os pobres voltarão a se alegrar com Javé, e os indigentes da terra ficarão felizes com o Santo de Israel.

c) cegos, surdos, coxos serão libertados (Is 35,5-6): Então, os olhos dos cegos vão se abrir, e se abrirão também os ouvidos dos surdos; os aleijados saltarão como cervo, e a língua do mudo cantará, porque jorrarão águas no deserto e rios na terra seca.

\footnotetext{
${ }^{10}$ Texto paralelo: Lc 7, 18-23.
} 
d) boa nova para os pobres e oprimidos (Is 61,1): O Espírito do Senhor Javé está sobre mim, porque Javé me ungiu. Ele me enviou para dar a boa notícia aos pobres, para curar os corações feridos, para proclamar a libertação dos escravos e pôr em liberdade os prisioneiros.

O discipulado de Jesus, para manter-se fiel à missão do Messias Jesus, há de corresponder aos anseios de libertação dos pobres que clamam por justiça, no contexto histórico do tempo presente. Como afirma o teólogo Benedito Ferraro,

Olhando hoje para a realidade da maioria dos povos da América Latina e Caribe, que sofrem em sua carne as marcas do abandono e da desolação, a Igreja se vê provocada a assumir sua causa e a colocar todas as energias na defesa da vida e na busca de justiça. (FERRARO, 2017, p. 246).

Não há como safar-se da responsabilidade diante do clamor dos pobres, que interpela a ação solidária e misericordiosa, não só individualmente mas, sobretudo, comunitariamente, por meio das Igrejas Cristãs.

Ao longo de dois mil anos de Cristianismo, as pessoas e comunidades eclesiais sempre se confrontaram com o clamor dos pobres e, de algum modo, procuraram dar resposta efetivas às necessidades imediatas dessa multidão de pessoas excluídas da vida com dignidade. A ação solidária não ficou circunscrita apenas a serviços meramente assistencialistas, mas dons e carismas especiais surgiram no trato com os pobres, espiritualidades foram sendo cultivadas a partir do envolvimento com a causa dos pobres, a partir dos desafios urgentes de contextos sociais e históricos bem determinados.

\section{0 clamor dos pobres na contemporaneidade}

Como foi explicitado acima, ao longo da história os pobres sempre interpelaram a consciência humana e, de modo especial, à consciência cristã. Contudo, foi a partir das repercussões do Concílio Vaticano II (1962-1965), com a preocupação de dar respostas objetivas aos desafios dos novos tempos, que a Igreja latino-americana passou a definir em seus documentos episcopais as marcas de 
uma Teologia e de uma Eclesiologia decolonizadas ${ }^{11}$, focadas nos desafios do Continente, cujo grande escândalo era impossível não enxergar: a situação da grande multidão de pessoas excluídas. Medellín e Puebla contribuíram decisivamente nesse processo, como bem salientou colocou José Comblin:

Antes de [Medellín e] Puebla, a Igreja latino-americana via-se a si mesma como o prolongamento da Igreja europeia, a franja periférica que se contentava em seguir os movimentos imprimidos nas Igrejas mais antigas, da Itália, da França, da Espanha, eventualmente, da Alemanha [...]. A voz de Medellín e Puebla tem como efeito colocar a palavra do Evangelho na concretude da história... Sem dúvida, Medellín e Puebla suscitaram criatividade. Dando apoio a iniciativas pastorais e missionárias específicas, as assembleias latino-americanas despertaram energias escondidas e desconhecidas e estimularam uma vida própria. Muitos agentes de pastoral e missionários leigos, eles ou elas, descobriram que eram também capazes de encontrar soluções e não simplesmente reproduzir modelos importados da Europa. (COMBLIN, 1999, p. 202203).

As Conferências Episcopais realizadas em Medellín e Puebla não somente estimularam uma vida própria à Igreja latino-americana, mas deram importante contribuição à Igreja de todos os continentes, ao escutar o clamor dos pobres e definir claramente a “opção preferencial pelos pobres” como desafio pastoral e teológico.

Para o teólogo Antonio Manzatto, “a maior herança que a Conferência de Puebla legou à Igreja foi, sem dúvida, a opção preferencial pelos pobres” (MANZATTO, 2019, p. 461). A apesar dos inúmeros conflitos e resistências, ao longo desses 40 anos, a opção preferencial pelos pobres tornou-se a marca original da Igreja do Continente e deu sua contribuição para o Patrimônio da Igreja universal (MANZATTO, 2019, p. 461):

\footnotetext{
${ }^{11} \mathrm{O}$ conceito em inglês é decoloniality, cuja tradução para espanhol e português não tem uma posição unânime. Entretanto, os termos "decolonialidade", "decolonial", já estão sendo muito usados, suprimindo-se o "s" para marcar uma distinção com o significado de "descolonizar" em seu sentido clássico. Desse modo, salienta-se que a intenção não é desfazer o colonial, ou seja, superar o momento colonial pelo momento pós-colonial. O decolonial implica em luta contínua, pois a colonização é um evento prolongado e de múltiplas irradiações. A colonização não diz respeito apenas à administração colonial direta sobre determinadas áreas do mundo, mas refere-se a uma estrutura de dominação que inclui a dimensão do conhecimento. Nesse sentido, fala-se em colonialidade e não apenas de colonialismo, discute-se sobre decolonialidade, e não simplesmente sobre descolonialismo. A decolonialidade, portanto, enquanto projeto epistêmico, implica em ser instrumento de análise da relação entre campos do conhecimento e o fenômeno da colonialida de. Trata-se de um lugar de crítica à epistemologia eurocêntrica e, consequentemente, dos discursos coloniais. Além disso, a decolonialidade diz respeito também à emergência de distintos saberes que surgem a partir de diferentes espaços de pensamento. Baseamo-nos aqui na tese de doutorado de Damázio (2011, p. 19, nota 2).
} 
a) ela passou a fazer parte de todos os planos de pastoral, esteve presente em todos os cursos de formação, em toda a reflexão teológica e em todos os processos eclesiais latino-americanos;

b) ela esteve presente quase que lateralmente na Conferência de Santo Domingo em 1992, sua força se fez sentir na Conferência de Aparecida em 2007 quando o próprio Papa Bento XVI, no discurso inaugural, a caracterizou como "inerente a toda fé cristológica”;

c) ela passou a ser estruturante da forma de a Igreja latino-americana ser; ela tornou-se chave hermenêutica da realidade eclesial do continente; ela estrutura o pensamento teológico, a dinâmica pastoral, a espiritualidade, a organização e a vivência do ser eclesial.

Apesar disso, o clamor dos pobres continua sendo um desafio às Igrejas Cristãs. Por um lado, incomoda as pessoas que tendem ao comodismo, confortavelmente instaladas na zona de conforto da alienação religiosa, preocupadas apenas em manter seu status social. Por isso, a opção preferencial pelos pobres foi o ponto mais combatido pelas forças conservadoras que se instalaram na Igreja, praticamente uma década depois de Puebla. De outro lado, o clamor dos pobres encontrou ressonâncias importantes, sobretudo, a partir da eleição do Papa Francisco que, de procedência latino-americana, sempre esteve atento aos dramas humanos em meio aos problemas sociais, políticas, econômicas, ambientais e culturais de todos os povos (MANZATTO, 2019, p. 461).

Nesse contexto, Francisco tem sugerido que se vá às periferias humanas, territoriais e existenciais, onde há sofrimento, solidão e degradação. Sem dúvida, é de lá que surge o clamor dos pobres, que interpela por alguma forma de solidariedade. A opção preferencial pelos que estão na periferia da vida deve desinstalar a Igreja, tornando-a “em saída”, missionária. É o que conclama o Papa na Exortação Apostólica Evangelii Gaudium: 
A Igreja «em saída» é uma Igreja com as portas abertas. Sair em direção aos outros para chegar às periferias humanas não significa correr pelo mundo sem direção nem sentido. Muitas vezes é melhor diminuir o ritmo, pôr de parte a ansiedade para olhar nos olhos e escutar, ou renunciar às urgências para acompanhar quem ficou caído à beira do caminho. Às vezes, é como o pai do filho pródigo, que continua com as portas abertas para, quando este voltar, poder entrar sem dificuldade. (EG 46).

Desse modo, a missão evangelizadora supõe da Igreja a capacidade "de sair de si mesma e ir para as periferias geográficas e existenciais do mistério da dor, do sofrimento, da violência, da injustiça, de toda miséria na vida humana", como afirma o filósofo Manfredo Araújo de Oliveira. E acrescenta:

Uma Igreja que, por sua pregação e estilo de vida, ajuda as pessoas a compreenderem que somos todos responsáveis pela formação das novas gerações, ajudando-as a reabilitar a "política", que é uma das formas mais altas da caridade, a fim de que cada vez mais cresça a participação das pessoas no enfrentamento dos problemas comuns, que se evite todo tipo de elitismo e que, imprimindo uma visão humanista à economia, erradique-se a pobreza (OLIVEIRA, 2018, p. 17).

Continua desafiante o clamor dos pobres para a consciência cristã, na perspectiva programática de construção do humano. Como está contemplado já no finalzinho do Documento de Puebla, é necessário criar no ser humano latinoamericano uma sã consciência social, um sentido evangélico crítico face à realidade, um espírito comunitário e um compromisso social. Tudo isso tornará possível uma participação livre e responsável, em comunhão fraterna e dialogante, para a construção da nova sociedade, verdadeiramente humana, penetrada de valores evangélicos. Ela deve ser modelada em comunhão com o Pai, o Filho e o Espírito Santo e dar resposta aos sofrimentos e aspirações de nossos povos, cheios de uma esperança que não poderá ser iludida. (DP 1308).

\section{Conclusão}

O resultado da pesquisa, exposto neste artigo, evidencia que o clamor dos pobres, ao longo da história, é algo que incomoda e leva necessariamente a algum tipo de atitude, mesmo que seja a de tapar os ouvidos para não escutar. O clamor dos pobres é o grito dos excluídos, gritaria de quem suplica, protesta, reclama. $\mathrm{O}$ 
clamor dos pobres desinstala porque soa como uma ameaça para quem se mantém na zona de conforto e, ao mesmo tempo, soa como apelo a atitudes práticas para quem é capaz de sensibilizar-se com o sofrimento humano.

Passados quarenta anos da Conferência de Puebla, pode-se afirmar que a opção preferencial pelos pobres foi consequência, do ponto de vista objetivo, do clamor dos pobres latino-americanos e, subjetivamente, da interpelação causada por esse clamor à consciência crítica de cristãos católicos que procuravam viver a dimensão evangélica da fé numa perspectiva prática libertadora junto às massas excluídas.

Esse tema é atualíssimo, pois dos quatro cantos da terra sobe ao céu um clamor cada vez mais impressionante: é o grito do povo que sofre e que reclama justiça, liberdade e respeito aos direitos da pessoa humana. Esse grito é ainda mais ensurdecedor hoje porque está unido ao grito da terra, que sofre pela devastação de sua biodiversidade causada pela ganância humana que explora os recursos todos os seres vivos do planeta, e seus recursos naturais.

Ao longo deste trabalho, fica evidente que o clamor dos que sofrem interpela a consciência para a compaixão solidária. É um imperativo ético à mudança de comportamento e à ação prática em prol da vida. As religiões, em seu papel de cultivar a sensibilidade humana para o convívio harmonioso com o semelhante, o ecossistema e o transcendente, têm contribuído desde tempos imemoriais nesse processo de humanização.

A Religião Cristã, por meio de suas Igrejas, depara-se com uma motivação a mais nessa escuta ao clamor dos pobres, interpelada que é pela prática compassiva e solidária de Jesus Cristo, em prol das multidões excluídas, tal como está contemplada nas narrativas dos Evangelhos.

Não há possibilidade, como nunca foi possível ao longo de dois mil anos de Cristianismo, de ser autenticamente cristão sem aderir à prática de Jesus no que tange à opção preferencial que Ele fez pelos pobres. Como religioso e fiel praticante 
dos textos sagrados judaicos, Jesus foi sensibilizado ao longo de sua vida a ouvir o clamor dos que sofrem, tal qual aprendeu desde criança na Torá (e, de modo especial no livro do Êxodo), nos Profetas e nos Escritos que contém a Sabedoria de Israel.

Ouvindo o clamor dos pobres, os Documentos da Igreja latino-americana, desde Medellín e Puebla, até os mais recentes, revelam que a opção preferencial pelos pobres tem sido a marca original da Igreja deste Continente e sua grande contribuição à Igreja universal. Fica evidente que nisso está a sua catolicidade.

Por fim, este artigo é uma forma de expressar a gratidão dos seus autores por terem tido a oportunidade de conhecerem a Teologia latino-americana durante a fase de estudos no Instituto de Teologia do Recife, na década de oitenta. Naquela oportunidade, estávamos inseridos nos trabalhos pastorais junto ao Movimento de Jovens do Meio Popular - MJMP, uma experiência que se espalhou pelo Nordeste em se fazer pastoral de juventude voltada para os jovens da periferia. Gratidão ao Deus de Jesus e à Arquidiocese de Olinda e Recife, por essa valiosa experiência teológica e pastoral, nos saudosos tempos do profeta Dom Hélder Câmara, quando esteve à frente de nossa Arquidiocese. Que o clamor dos pobres continue guiando nossos ouvidos às periferias existenciais, como tão bem sugere o Papa Francisco.

\section{REFERÊNCIAS}

BARBAGLIO, Giuseppe. Jesus, hebreu da Galileia: pesquisa histórica. São Paulo: Paulinas, 2011.

BÍBLIA DE JERUSALÉM. Ed. rev. e ampl. São Paulo: Paulus, 2002.

BOFF, Leonardo. O caminhar da Igreja com os oprimidos: do vale das lágrimas rumo à terra prometida. Petrópolis: Vozes, 1988.

COMBLIN, José. Puebla: vinte anos depois. Perspectiva Teológica, Belo Horizonte, v. 31, p. 201-222, 1999. 
CROATTO, José Severino. As linguagens da experiência religiosa: uma introdução à fenomenologia da religião. São Paulo: Paulinas, 2001.

DAMÁZIO, Eloise da Silveira Petter. Colonialidade e decolonialidade da (anthropos)logia jurídica: da uni-versalidade à pluri-versalidade epistêmica. Tese (Doutorado em Direito) - Universidade Federal de Santa Catarina, Florianópolis, 2011. Disponível em: https://repositorio.ufsc.br/bitstream/handle/123456789/95973/299229.pdf?sequence=1 \&isAllowed=y. Acesso em: 31 maio 2018.

DIALOGO SOBRE LA MISERIA HUMANA! Jueves, 5 feb. 2009. Disponível em: http://vengopronto.blogspot.com/2009/02/dialogo-sobre-la-miseria-humana.html. Acesso em: 23 jun. 2019.

DICIONÁRIO ENCICLOPÉDICO DA BÍBLIA. São Paulo: Loyola: Paulus: Paulinas, 2013.

DOCUMENTO DE PUEBLA. Evangelização no presente e no futuro da América

Latina. Conclusões da Conferência de Puebla. São Paulo: Paulinas, 1979.

ECLESIASTES BABILÔNICO. Disponível em: http://vengopronto.blogspot.com/ 2009/02/dialogo-sobre-la-miseria-humana.html. Acesso em: 23 jun. 2019.

ELIADE, Mircea. História das crenças e das ideias religiosas: da Idade da Pedra aos mistérios de Elêusis. Rio de Janeiro: Zahar, 2010. v. 1.

FERRARO, Benedito. Pobreza da Igreja. In: GODOY, Manoel; AQUINO JÚNIOR, Francisco (org.). 50 anos de Medellín: revisitando os textos, retomando o caminho. São Paulo: Paulinas, 2017. cap. 16, p. 246-266.

FRANCISCO CONVIDA BISPOS A IREM ÀS "PERIFERIAS EXISTENCIAIS". Disponível em: https://noticias.cancaonova.com/mundo/francisco-convida-bispos-a-irem-asperiferias-existenciais/. Acesso em: 28 ago. 2019.

FRANCISCO, Papa. Exortação Apostólica Evangelii Gaudium. Disponível em: http://w2.vatican.va/content/francesco/pt/apost_exhortations/documents/papafrancesco_esortazione ap_20131124_evangelii-gaudium.html. Acesso em: 29 ago. 2019.

GARAUDY, Roger. Apelo aos vivos. Rio de Janeiro: Nova Fronteira, 1981.

HARARI, Yuval Noah. Uma breve história da humanidade. Porto Alegre: L\&PM, 2018.

KUNG, Hans. Religiões do mundo: em busca dos pontos comuns. São Paulo: Verus, 2004 .

MACKENZIE, John L. Dicionário bíblico. São Paulo: Paulinas, 1983. 
MANZATTO, Antonio. Opção preferencial pelos pobres. In: SOUZA, Ney de;

SBARDELOTTI, Emerson (org.). Puebla: Igreja na América Latina e no Caribe. Opção pelos pobres, libertação e resistência. Petrópolis: Vozes, 2019. Parte 5, cap. 1, p. 451-462.

OLIVEIRA, Manfredo Araújo de. O Papa Francisco e o mundo de hoje. In: AQUINO JÚNIOR, Francisco de; ABDALLA, Maurício; SÁVIO, Robson (org.). Papa Francisco com os movimentos populares. São Paulo: Paulinas, 2018. cap. 1, p. 15-32.

PIAZZA, Waldomiro O. Religiões da humanidade. 2. ed. ampl. São Paulo: Loyola, 1991.

ROZOWYKWIAT, Tereza (org.). Meus queridos amigos: as crônicas de Dom Hélder Câmara. Recife: Cepe, 2016.

SCHERER, Burkhard (org.). As grandes religiões: temas centrais comparados. Petrópolis: Vozes, 2005.

SMITH, Huston. As religiões do mundo: nossas grandes tradições de Sabedoria. São Paulo: Cultrix, 2007.

SOUZA, Ney de. Puebla, antecedentes e evento. In: SOUZA, Ney de; SBARDELOTTI, Emerson (org.). Puebla: Igreja na América Latina e no Caribe. Opção pelos pobres, libertação e resistência. Petrópolis: Vozes, 2019. Parte 1, cap. 2, p. 69-81. 